\title{
Use of BCG vaccine for enhancement the immune response of sheep to Rev.1 Vaccination
}

\author{
S. M. S. El-Ayouby, O. R. Salib, H. K. El-Deen \\ Veterinary serum and Vaccines Research Institute Abbassia, Cairo.
}

\begin{abstract}
This study was conducted to evaluate the protective effect of Brucella melitensis Rev.1 and the use of BCG vaccine as immunostimulant by subcutaneous injection in Guinea pigs. Lab. animals were divided into 8 groups: Combined Rev.1 and BCG vaccines injected in the $1^{\text {st }}$ group \& both vaccines were injected simultaneously in the $2^{\text {nd }}$ group. Three groups sensitized with BCG vaccine then injected with Rev.1 vaccine one week, two week \& three weeks intervals respectively. Other two groups were injected with BCG and Rev.1 vaccine individually. The last one was unvaccinated control. All injected animals showed resistance to infection with $16 \mathrm{M}$ strain $(90 \%, 80$ $\%, 80,60 \%, 70 \%, 0 \%$ and $70 \%$ respectively).Thus animals vaccinated with bivalent Rev.1 and BCG vaccines (in one shot) showed the best protective level to infection.
\end{abstract}

Brucellosis is a major zoonotic disease that causes abortion in wild and domestic animals and undulant fever in humans. The disease is transmitted to humans by consumption of dairy products or by direct contact with infected animals or carcasses (Young 1983 and 1995). On contact, brucellae penetrate the skin or mucosal membranes and enter the lymph nodes, which become hemorrhagic, resulting in bacteremia, which facilitates dissemination throughout the body. During the early phase of infection, brucellae invade macrophages, adapt to the acidic environment, and multiply in the vacuolar compartments (Porte et al., 1999). Brucella prevents phagosome lysosome fusion (Baldwin and Winter, 1994; Pizarro-Cerda et al., 1998). The infection involves many tissue types and organs. The spread of the disease is controlled in developed countries by livestock testing, vaccination, and slaughter programs, (Corbel, 1997).

The Elberg B. melitensis Rev.1 strain (Porte et al., 1999) is the small ruminant's equivalent vaccine as is B. abortus S19 in cattle. Since 1957, when first used in international pilot scale studies, this vaccine had been used worldwide showing excellent results in the control of B. melitensis (Alton and Elberg, 1967; Elberg, 1981 and 1996). Because of its wide use different producers became interested in mass production of the vaccine for commercial purposes. The seed stock had been distributed among the producers, each propagating it similarly, however, losing to a certain extent the quality of the vaccine. As a result some countries have encountered adverse effects with the vaccine. These results led to application of the Rev-1 vaccine in a regional control program for the Middle East countries, proposed by the FAO/WHO/OIE expert committee.

Bacillus of Calmette and Guerin (BCG) is a well known immunostimulant agent against a variety of human and animal diseases. BCG or its active fragments have proved to be effective therapy and can stimulate a cross resistance to unrelated organisms including protozoa, fungi, bacteria and viruses as well as to certain transplanted tumors (Barakat et al., 1984).

Therefore the present study was planned to clarify the following aspects: detecting the ability of Rev-1 vaccine to combat challenge with Brucella virulent strain (16 M) alone and in combination with $\mathrm{BCG}$ vaccine.

\section{Materials and methods}

Experimental animals. One hundred and twenty Guinea-pigs from 300-400 grams weight were used. All animals were Brucella free through serological screening using Brucella agglutination test. They were divided into eight groups each of 15 animals.

Brucella strain.Virulent Brucella melitensis $16 \mathrm{M}$.

(USDA, vs. Nat. Vet, services lab, Ames Iowa 50010 USA )

Brucella antigens. Rose Bengal (RBA) and Tube agglutination antigens. They were prepared in VSVRI .Abbassia , Cairo,Egypt

Freeze dried vaccines. Smooth Brucella 
Table (1): animal vaccination and challenge scheme.

\begin{tabular}{|c|c|c|c|c|c|c|c|c|}
\hline \multirow{3}{*}{$\begin{array}{l}\text { Animal } \\
\text { group }\end{array}$} & \multirow{3}{*}{$\begin{array}{c}\text { Guinea } \\
\text { pigs } \\
\text { No. }\end{array}$} & \multicolumn{6}{|c|}{ Vaccination } & \multirow{3}{*}{ Challenge } \\
\hline & & \multicolumn{4}{|c|}{$1^{\text {st }}$ vaccination } & \multicolumn{2}{|c|}{$2^{\text {nd }}$ vaccination } & \\
\hline & & $\begin{array}{l}\text { Type of } \\
\text { vaccine }\end{array}$ & $\begin{array}{l}\text { Vaccination } \\
\text { condition }\end{array}$ & dose & route & $\begin{array}{l}\text { Type of } \\
\text { vaccine }\end{array}$ & interval & \\
\hline 1 & 15 & $\begin{array}{c}\text { BCG } \\
+ \\
\text { Br. m. Rev-1 }\end{array}$ & $\begin{array}{c}\text { Mixed } \\
\text { combined }\end{array}$ & $\begin{array}{c}0.1 \mathrm{ml} \\
+ \\
1 \mathrm{ml}\end{array}$ & $\mathrm{s} / \mathrm{c}$ & Non & - & \multirow{8}{*}{ 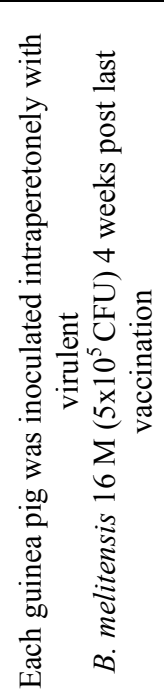 } \\
\hline 2 & 15 & $\begin{array}{c}\text { BCG } \\
\text { and } \\
\text { Br. m. Rev - } \\
1\end{array}$ & $\begin{array}{l}\text { Simultaneous } \\
\text { At the same } \\
\text { time }\end{array}$ & $\begin{array}{c}0.1 \mathrm{ml} \\
1 \mathrm{ml}\end{array}$ & $\mathrm{s} / \mathrm{c}$ & Non & - & \\
\hline 3 & 15 & BCG & $\begin{array}{c}1 \text { st } \\
\text { preliminary }\end{array}$ & $0.1 \mathrm{ml}$ & $\mathrm{s} / \mathrm{c}$ & $\begin{array}{c}\text { Br. m. Rev } \\
-1\end{array}$ & $\begin{array}{c}1 \\
\text { week }\end{array}$ & \\
\hline 4 & 15 & $\mathrm{BCG}$ & $\begin{array}{c}1 \text { st } \\
\text { preliminary }\end{array}$ & $0.1 \mathrm{ml}$ & $\mathrm{s} / \mathrm{c}$ & $\begin{array}{c}\text { Br. m. Rev } \\
-1\end{array}$ & $\begin{array}{c}2 \\
\text { weeks }\end{array}$ & \\
\hline 5 & 15 & BCG & $\begin{array}{c}1 \text { st } \\
\text { preliminary }\end{array}$ & $0.1 \mathrm{ml}$ & $\mathrm{s} / \mathrm{c}$ & $\begin{array}{c}\text { Br. m. Rev } \\
-1\end{array}$ & $\begin{array}{c}3 \\
\text { weeks }\end{array}$ & \\
\hline 6 & 15 & BCG & Single & $0.1 \mathrm{ml}$ & $\mathrm{s} / \mathrm{c}$ & Non & - & \\
\hline 7 & 15 & $\begin{array}{c}\text { Br. m. Rev - } \\
1\end{array}$ & Single & $1 \mathrm{ml}$ & $\mathrm{s} / \mathrm{c}$ & Non & - & \\
\hline 8 & 15 & \multicolumn{6}{|c|}{ Control unvaccinated guinea pigs } & \\
\hline
\end{tabular}

- $\quad$ Br. m. Rev-1 = Brucella melitensis Rev-1 vaccine. s/c = subcutaneous.

- * $=$ Rev $-11 \times 10^{8}$ CFU and BCG $2 \times 10^{4}$

melitensis Rev-1 vaccine. Freeze dried BCG vaccine. (VSVRI .Abbassia, Cairo,Egypt).

Potency test. (Alton, 1988 ; OIE 2000) All groups were challenged with virulent Brucella melitensis $16 \mathrm{M}\left(5 \times 10^{5} \mathrm{CFU} \mathrm{I/P}\right)$ four week after vaccination with Rev.1 . The guinea pigs injected with $B$. melitensis, were weighed and killed after 8 weeks post -inoculation. The spleen of each animal was weighed and counted for Brucella $16 \mathrm{M}$.

Blood sampling. Heparinized blood samples: Samples were collected from each group at 4, 11, 18 and 25 days for estimation of cell mediate immune response. Serum samples were collected every 2 weeks for evaluation of humoral immune response.

Evaluation of the immune response. Humoral immune response:Rose Bengal (RBT) and Standard tube agglutination tests (STAT) were performed according to Alton,(1988).

Cell mediated immune response:It was evaluated by lymphocyte transformation test according to Lucy(1974) and (1977) modified by Charles et al.,(1978) ; Lee (1984) as follow: 2 $\mathrm{ml}$ of blood was obtained from vaccinated Guinea pigs using heparinized syringe.

The blood was diluted 1: 1 with PBS ( $\mathrm{pH}$ 7.2) then carefully layered on the surface of equal volume of lymphocyte separation medium (Ficol Hypaquc) (Flow Lab.UK) in a sterile plastic tube. The tube was centrifuged at 2400 rpm for 30 minutes and the separated buffy coat cells were washed three times in RPM 1. Viable lymphocytes were adjusted to a final concentration of $5 \times 10$ (cells / ml RPM I containing foetal Calf Serum (FCS) and each well of the tissue culture microplates received $0.5 \times 10^{6}$ cells in $0.1 \mathrm{ml}$. Flat bottomed sterile 96 well tissue- culture microplates were used for this purpose and the wells PHA ( 10 ul $)$ stimulated cultures, control unstimulated cells and control medium without cells. The plates were covered and incubated at $37^{\circ} \mathrm{C}$ in humid $\mathrm{CO}_{2}$ atmosphere $(5-10 \%)$ for 72 hours. Evaluation of lymphocyte blastogenesis by MTT (Mosmann, 1983): In a dark place, MTT was added as 10.0 ul MTT/ well. Following incubation, 50 ul of $10 \%$ SDS solution were added for each well and reincubated overnight at $37^{\circ} \mathrm{C}$ in $5 \% \mathrm{CO}_{2}$. The plates were read at $570 \mathrm{~nm}$ by micro ELISA reader.

Experimental design. G.Pigs was divided into eight groups each of 15 animals as shown in Table (1)

\section{Results and Discussion}


Table (2): Comparison of humeral immune response between groups of G.pigs vaccinated with B.melitensis Rev.1 and BCG vaccine S/C and challenge with $5 \times 105 C F U$ B. melitensis $16 \mathrm{M}$.

\begin{tabular}{|c|c|c|c|c|c|c|c|c|c|c|c|c|c|c|c|c|}
\hline \multirow{2}{*}{$\begin{array}{c}\text { Weeks post } \\
\text { Rev-1 } \\
\text { vaccination }\end{array}$} & \multicolumn{8}{|c|}{ Results of Rose Bengal test (+ve \%) } & \multicolumn{8}{|c|}{ Results of Tube agglutination test ( mean IU/ml) } \\
\hline & $\begin{array}{c}\text { Group } \\
1\end{array}$ & $\begin{array}{c}\text { Group } \\
2\end{array}$ & $\begin{array}{c}\text { Group } \\
3\end{array}$ & $\begin{array}{c}\text { Group } \\
4\end{array}$ & $\begin{array}{c}\text { Group } \\
5\end{array}$ & $\begin{array}{c}\text { Group } \\
6\end{array}$ & $\begin{array}{c}\text { Group } \\
7\end{array}$ & $\begin{array}{c}\text { Group } \\
8\end{array}$ & $\begin{array}{c}\text { Group } \\
1\end{array}$ & $\begin{array}{c}\text { Group } \\
2\end{array}$ & $\begin{array}{c}\text { Group } \\
3\end{array}$ & $\begin{array}{c}\text { Group } \\
4\end{array}$ & $\begin{array}{c}\text { Group } \\
5\end{array}$ & $\begin{array}{c}\text { Group } \\
6\end{array}$ & $\begin{array}{c}\text { Group } \\
7\end{array}$ & $\begin{array}{c}\text { Group } \\
8\end{array}$ \\
\hline 2 & - & - & - & $\begin{array}{c}- \\
80 \%\end{array}$ & - & - & $-\overline{0}$ & - & - & - & - & - & - & - & - & \\
\hline 4 & - & $60 \%$ & $80 \%$ & $80 \%$ & - & - & $80 \%$ & - & - & 93 & 106 & 106 & - & - & 106 & - \\
\hline 6 & $60 \%$ & $80 \%$ & $100 \%$ & $100 \%$ & - & - & $100 \%$ & - & 93 & 186 & 106 & 106 & - & - & 106 & - \\
\hline \multicolumn{17}{|c|}{ Animal challenged with virulent $B$. melitensis $16 \mathrm{M} 5 \times 10^{5} \mathrm{CFU} 8$ weeks after vaccination with $B . m e l i t e n s i s$ Rev-1. } \\
\hline 10 & $60 \%$ & $80 \%$ & $80 \%$ & $80 \%$ & $80 \%$ & $100 \%$ & $80 \%$ & $100 \%$ & 134 & 40 & 134 & 40 & 134 & 640 & 160 & 848 \\
\hline 12 & - & $100 \%$ & $100 \%$ & $100 \%$ & $100 \%$ & $100 \%$ & $100 \%$ & $100 \%$ & - & 268 & 268 & 160 & 160 & 744 & 186 & 848 \\
\hline 14 & - & $100 \%$ & $100 \%$ & $100 \%$ & $100 \%$ & $100 \%$ & $100 \%$ & $100 \%$ & - & 134 & 160 & 106 & 106 & 744 & 268 & 848 \\
\hline 16 & - & $100 \%$ & $100 \%$ & $100 \%$ & $100 \%$ & $100 \%$ & $100 \%$ & $100 \%$ & - & 80 & 93 & 93 & 93 & 848 & 160 & 848 \\
\hline
\end{tabular}

Group 1: Mixed BCG+B .melitensis Rev-1. Group 2: Simultaneous BCG+B. melitensis Rev-1.

Group 3: BCG+B. melitensis Rev-1 ( 1 week interval). Group 4: BCG+B. melitensis Rev-1 (2weeks interval).

Group 5: BCG+B. melitensis Rev-1 (3 weeks interval). Group 6: BCG vaccine.

Group 7: B. melitensis Rev-1vaccine. Group 8: control un vaccinated guinea pigs.

Table (3): Spleen count assay among Guinea pigs vaccinated with Rev-1 with or without BCG vaccine and challenged with 5x105 CFU B. melitensis M16

\begin{tabular}{|c|c|c|c|c|c|c|c|c|}
\hline Groups of Guinea pigs & Group1 & Group2 & Group3 & Group4 & Group5 & Group6 & Group7 & Group 8 \\
\hline Mean body weight in grams & 360.3 & 424.8 & 375 & 536.1 & 508.9 & 542 & 361.6 & 365 \\
\hline Mean spleen weight in grams & 0.6 & 0.9 & 1.10 & 1.4 & 0.9 & 1.62 & 0.62 & 1.95 \\
\hline Mean spleen weight/ body weight ratio & 0.17 & 0.21 & 0.29 & 0.26 & 0.18 & 0.30 & 0.17 & 0.65 \\
\hline Mean colonies / whole spleen & 50 & 200 & 200 & 430 & 266 & 16.600 & 250 & 20.500 \\
\hline Mean colonies / gram spleen & 83.3 & 222.2 & 181.1 & 307.1 & 295.5 & 10.246 & 403.2 & 10.51 \\
\hline $\log Y$ & 1.5 & 1.9 & 1.9 & 2.2 & 2.0 & 3.6 & 2.0 & 3.7 \\
\hline Protection & $\mathrm{P}$ & $\mathrm{P}$ & $\mathrm{P}$ & $\mathrm{P}$ & $\mathrm{P}$ & Non-P & $\mathrm{P}$ & Non-P \\
\hline percent of protection and non-protection & $90 \%$ & $80 \%$ & $80 \%$ & $60 \%$ & $70 \%$ & $0 \%$ & $70 \%$ & $0 \%$ \\
\hline
\end{tabular}

Animals: Challenge 8 weeks after vaccination with 5x105 CFU B. melitensis M $16 . \quad$ Animals: slaughtered 8 weeks after challenge.

According to OIE (2000) $\mathrm{X}=$ number of virulence Brucella organisms per spleen. $\mathrm{Y}=\log (\mathrm{X} / \log \mathrm{X})=$ response and protected animals. $<2.5$

Group 1: Mixed BCG+B. melitensis Rev-1.

Group 3: BCG+ B.melitensis Rev-1 ( 1 week interval)

Group 2: Simultaneous BCG+B.melitensis Rev-1.

Group 5: BCG+ B melitensis Rev-1 (3 weeks interval).

Group 4: BCG+ B melitensis Rev-1 (2weeks interval).

Group 7: B.melitensis Rev-1 vaccine.

Group 6: BCG vaccine.

Group 8: control un vaccinated guinea pigs. 
Table (4): Results of lymphocyte transformation test in Guinea pigs vaccinated with B. melitensis Rev-1 and or BCG

\begin{tabular}{ccccc}
\hline \multirow{2}{*}{$\begin{array}{c}\text { Animal } \\
\text { groups }\end{array}$} & \multicolumn{4}{c}{ Results of lymphocyte transformation test } \\
\cline { 2 - 5 } & $\mathbf{4}$ days & $\mathbf{1 1}$ days & $\mathbf{1 8}$ days & $\mathbf{2 5}$ days \\
\hline 1 & 0.495 & 0.399 & $0 . .312$ & 0.300 \\
2 & 0.426 & 0.323 & 0.305 & 0.300 \\
3 & 0.400 & 0.372 & 0.331 & 0.303 \\
4 & 0.403 & 0.386 & 0.356 & 0.319 \\
5 & 0.411 & 0.391 & 0.364 & 0.327 \\
6 & 0.282 & 0.388 & 0.385 & 0.375 \\
7 & 0.420 & 0.390 & 0.308 & 0.300 \\
8 & 0.197 & 0.223 & 0.219 & 0.187 \\
\hline
\end{tabular}

Group 1: Mixed BCG+B. melitensis Rev-1.

Group 2: Simultaneous BCG+ B. melitensis Rev-1.

Group 3: BCG+ B. melitensis Rev-1 ( 1 week interval). Group 4: BCG+ B. melitensis Rev-1 (2weeks interval).

Group 5: BCG+ B. melitensis Rev-1 (3 weeks interval). Group 6: BCG vaccine. Group 7: B. melitensis Rev-1vaccine.

Group 8: un vaccinated control Guinea pigs

Results are shown in Tables 2, 3 and 4. The humoral immune response of different groups of vaccinated guinea pigs was evaluated using Rose Bengal and tube agglutination tests (Table 2). At the fourth week after vaccination the $2^{\text {nd }}, 3 \mathrm{rd}, 4^{\text {th }}$ and $7^{\text {th }}$ groups gave $60 \%, 80 \%, 80 \%$ and $80 \%$ positive respectively in Rose Bengal test and 93, 106, 106 and $106 \mathrm{IU} / \mathrm{ml}$ respectively in tube agglutination test. While the $1^{\text {st }}, 5^{\text {th }}, 6^{\text {th }}$ and $8^{\text {th }}$ groups gave negative in Rose Bengal and tube agglutination tests.

At the $6^{\text {th }}$ week after vaccination the $1^{\text {st }}, 2^{\text {nd }}$, $3^{\text {rd }}, 4^{\text {th }}$ and $7^{\text {th }}$ groups gave $60 \%, 80 \%, 100 \%, 100 \%$ and $100 \%$ positive respectively in Rose Bengal test and 93, 186, 106, 106 and106 IU/ml. respectively in tube agglutination test. While $5^{\text {th }}$, $6^{\text {th }}$ and $8^{\text {th }}$ groups gave negative results in both tests.

Two weeks after challenge with the virulent Brucella strain all the groups gave positive results in Rose Bengal and tube agglutination tests. While at the 4th, 6th and 8th weeks after challenge only the 1st group gave negative with the both tests.

Control unvaccinated guinea pigs showed high antibody titers after challenge with virulent Brucella strain (100\% +ve with Rose Bengal and $848 \mathrm{IU} / \mathrm{ml}$ with tube agglutination test).

The potency of different preparations was evaluated as shown in Table (3). The 1st group gave the best results ( $\log$ Y 1.5 and gave $90 \%$ protection) while the 6th group gave $0 \%$ protection. Lymphocyte transformation test was performed and the results were shown in Table
(4). The 6th group (vaccinated with BCG only) was the least titer among the different groups, while the 1st group (vaccinated with mixed bivalent vaccine) gave the highest titer at the 4th day.

The members of the genus Brucella are gram-negative, facultative intracellular coccobacilli that cause brucellosis in many animal species and humans. The protective immune response against Brucella bacteria involves both humoral and cell-mediated immunity (Al-Mariri et al., 2002). Acquired immunity against intracellular bacteria is T-cell dependent which means $\mathrm{T}$ cells play the major role in protection against these organisms. Immunity against Brucella species depends on antigen-specific T-cell mediated killing of this organism (Oliveira et al., 1998). In addition to the central role of the macrophage in Brucella infection, others cells of the immune system are influenced by the interactions between bacteria and host. These cells can counteract the intramacrophagic development of the bacteria and finally influence the further development of the host defense (Oliveira et al., 1998; Dornand et al., 2002)

The present study describes the cross immunity between Rev-1 and BCG vaccines.

On injection of BCG and Rev-1 vaccines in guinea pigs with intervals 1,2 and 3 weeks gave protection percent $80 \%, 60 \%$ and $70 \%$ respectively, as will as Rev-1 vaccine. This means that BCG vaccine did not enhance the protective effect of Rev-1 vaccine in these 
circumstances.

On the other hand, vaccination of guinea pigs with the mixed vaccine (Rev-1+ BCG vaccine) gave $90 \%$ protection against Brucella melitensis virulent strain $(16 \mathrm{M})$.

Among non-specific immunity, BCG vaccine gave no protection against challenge with Brucella melitensis virulent strain $(16 \mathrm{M})$.

These results disagreed with Elberg et al., (1957) who studied the non-specific immunity, where vaccination by BCG or by an effective anti brucellosis reagent induces protection in either cases against both Mycobacterium tuberculosis and Brucella melitensis. Also Barakat, (1979) studied the use of BCG as a heterologous vaccine against Corynebacterium bovis. BCG vaccine proved to be very efficient against caseous lymphadenitis of sheep.

Buddl and Thomson (1995) showed that S/C vaccination of calves with $104-106 \mathrm{CFU}$ of BCG caused a significant reduction in the prevalence and severity of T.B. lesions. Subcutaneous vaccination of BCG results in the induction of cell mediated immunity as manifested by (CD4+ T helper type) cells as well as (CD8+cytotoxic T-lymphocyte). These responses are accompanied by the synthesis nonspecific and cell mediated immunity.

In tables 2, 3, 4 BCG vaccine alone failed to provide protection against virulent $16 \mathrm{M} \mathrm{B}$. melitensis challenge. Combined vaccines BCG and Rev.1 increased the level of protection against pathogenic $16 \mathrm{M}$ in comparison to use Rev.1 vaccine alone (table 3). Table 3 may explain that using both vaccines combined together and injected in one site S/C may lead to hyper activity of the same draining L.N. due to BCG as immune modulator and increased in the cell mediated immunity, this phenomenon was observed by Miller et al., (1973).

In this study BCG used as a vaccine vector to induce protection against Brucella challenge. The cross-protection strategy has been used in the development of new vaccination against Brucellosis with good protective effect.

Usage of BCG in combined vaccines was studied by many investigators, Mazantini et al., (2004) developed a combined Mycobacterium bovis BCG vaccine with dephtheria, pertusis and tetanus by administration sub immunizing dose of the diphtheria-tetanus toxoid vaccine. This combination induced $75 \%$ protection in mice challenged with 100 minimum lethal doses (MLD) of tetanus toxin this combination produced of a more effective immune response against both diseases. Also, Osman, et al., (1991) indicated the safety and efficiency of simultaneous inoculation of cattle with rinderpest and BCG vaccines without impairing the response of individual vaccines.

From the above mentioned results, it may be concluded that vaccination of guinea pigs with Rev-1 and BCG vaccines in one shot $(\mathrm{S} / \mathrm{C})$ is effective in minimizing the pathogenic effect of Brucella melitensis virulent strain (16 M) and gives $90 \%$ protection.

\section{References}

Al-Mariri, A.; Tibor, A.; Lestrate, P.; Mertens, P.; De Boll, X. and Letesson, J. J. (2002): Yersinia enterocolitica as a vehicle for a naked DNA vaccine encoding Brucella abortus bacterioferritin or P39 antigen. Infect. Immun. 70 (4): 1915-1923.

Alton,G.G. (1988): Techniques for the brucellosis laboratory Institute National de la Recherdre . A gronomique 147 rue de Iuniversit 75007 ,paris.

Baldwin, C. L. \& Winter, A. J. (1994): Macrophages and Brucella. Immunol. Immunol. Ser. 60, 363-380.

Barakat, 1979: Immunization against caseous lymphadenitis of sheep using

attenuated bovine tubercle bacillus of Calmette and Guerin (BCG). Bult.Off. int. Epiz.91,(9-10), 679-692

Barakat,A.A. ; Nafie,E.K. ; Saber,M.S. ; Nasar,M.I. ; Michael.A. and EL-Ebeedy,A.A. (1984): Effect of vaccination with BCG on sheep pox.

Assiut Vet.Med.J.Vol.13,No.25.

Budl, B. M.; Keen, D. and Thomson G .(1995): Protection cattle from bovine tuberculosis by vaccination with BCG by the respiratory or subcutaneous route, but not by vaccination with killed Mycobacterium vaccae Res.Vet.Sci $1995 ; 59: 10-16$.

Charles, M.C. ; Rubi. A. ; Henry,R. and Boss,J.R. (1978): Suspension of the mitogen stimulated blastogenic response during reticuloendothelialiosis virus induced tumerigenesis. Immunol.120, 1313-1320.

Corbel, M. J. (1997): Brucellosis: an overview. Emerg. Infect. Dis. 3, 213-221.

Dornand, J.; Gross, A.; Lafont, V.; Liautard, J.; Oliaro, J. and Liautard, J. P. (2002): The innate immune response against Brucella in humans. Vet. Microbiol. , 20; 90 (1-4): 383-394.

Elberg, S. S. (1981): Rev.1 Brucella melitensis vaccine. Part II. 1986-1980. Vet.Bull.51:67-73.

Elberg, S. S. (1996):

Rev.1 Brucella melitensis vaccine. Part III. 1981-1995.

Vet.Bull.66:1193-1200.

Elberg, S. S.; Schneider, P. and Forg, J. (1957): Crossimmunity between Brucella melitensis and Mycobacterium tuberculosis. J. of exp. Medicine

$106 ; 545-554$.

Handerson, D.W.;Lancaster, M. C.; Packman,L.and Peacock,S. (1956): The influence of a pre-existing respiratory infection on the course of another super-imosed by the respiratory route. Brit.J.Exp.Path., ,37,597.

Lee, L. F. (1984): Proliferation response of chick B and T lymphocytes to mitogens. Vet. Med., 15: 44-52.

Lucy(1974): In vito assay of mitogen stimulation of prepheral lymphocyte. Avian disease. 18: 602-608.

Lucy(1977): Chicken lymphocyte stimulation by mitogens A micro assay with whole blood cultures. Avian disease.22: 
269-307.

Mazzantini, R. P.; Miyaji, E. N.; Dias, W. O.; Sakauchi, D.; Nascimento, A. T. O.; Raw, I.; Winter, N.; Gicquel, B.; Rappuoli, R. and Leite, L. C. C. (2004): Adjuvant activity of Mycobacterium bovis BCG expressing CRM197 on the immune response induced by BCG expressing tetanus toxin fragment C. Vaccine, 22: 740-746.

Miller, T. E.; Mackaness, G. B. and Lagrange, P. H. (1973): Immunopotentation of BCG. II Modulation of the response to sheep red cells. J. Nat. Cancer Inst., 51: 16691678 .

Mosman,T.(1983): Rapid colorimetric assay for cellular growth and cytotoxicity assays. Immunol.Methods,55-65.

Oliveira, S. C.; Harms, J. S.; Rech, E. L.; Rodarte, R. S.; Bocca, A. L.; Goes, A. M. and Splitter, G. A. (1998): The role of T-cell subsets and cytokines in the regulation of intracellular bacterial infection. Braz.

J. Med.Biol. Res., 31 (1): 77-84.

OIE Manual of standards for diagnosis and vaccines, 4th edition 2000 .
Osman,O.A.; Mouaz,M.A.; $\quad$ EL-Zeidy,S.A.S.; Dimitri,R.A.; Gergis,S.M. and Yousef,R.R. (1991): Serological Response of cattle to synchronous vaccination with Rinderpest and BCG vaccines. Egypt.J.Agricult.Res. 69 (4): 1031-1039.

Pizarro-Cerda, J., Meresse, S., Parton, R. G., van der Goot, G., Sola-Landa, A., Lopez-Goni, I., Moreno, E. \& Gorvel J. P. (1998): Brucella abortus Transits through the Autophagic Pathway and Replicates in the Endoplasmic Reticulum of Nonprofessional Phagocytes. Infect. Immun. 66, 5711-5724.

Porte, F., Liautard, J. P. \& Kohler, S. (1999): Early Acidification of Phagosomes Containing Brucella suis Is Essential for Intracellular Survival in murine macrophages. Infect. Immun. 67, 4041-4047.

Young, E. J. (1983): Human brucellosis. Rev. Infect. Dis. 5, 821-842.

Young, E. J. (1995): An overview of human brucellosis. Clin. Infect. Dis. 21, 283-289.

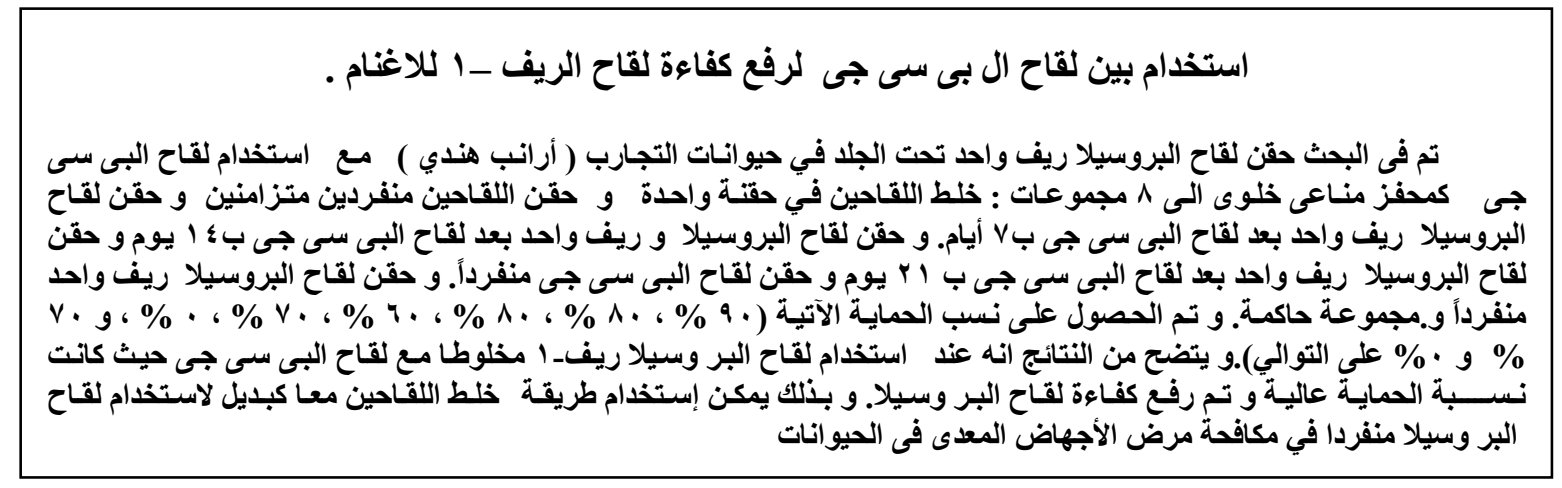

